\title{
Research Group Berbasis Lesson Study Pembelajaran untuk Meningkatkan Profesionalitas Guru KKG Gusek 2 Tenggarang Kabupaten Bondowoso
}

\author{
Fajar Surya Hutama ${ }^{1^{*}}$, Agustiningsih ${ }^{2}$ \\ 1,2Program Studi Pendidikan Guru Sekolah Dasar, Jurusan Ilmu Pendidikan, Fakultas Keguruan dan Ilmu Pendidikan, Universitas Jember
}

\section{A R T I C L E I N F O}

\section{Article history:}

Received 19 Januari 2018

Received in revised form

12 Februari 2018

Accepted 28 Maret 2018

Available online 20 Mei 2018

\section{Kata Kunci:}

Research Group, Lesson Study, \& Profesionalitas Guru

Keywords:

Research Group, Lesson

Study, \& Teacher

Professionality

\begin{abstract}
A B S T R A K
Lesson Study adalah bentuk kegiatan untuk peningkatan kualitas pembelajaran dengan model kegiatan Plan, Do, See (refleksi). Target luaran dari pelaksanaan pengabdian ini: (1) Mengembangkan strategi pembelajaran inovatif; (2) Hasil PTK yang Berkualitas; (3) Peningkatan Soft Skill dalam Publikasi Ilmiah. Metode pelaksanaan program pengabdian bagi Dosen Pemula ini adalah pelatihan, pembimbingan, tugas mandiri, dan praktek penelitian di kelas. Secara terperinci kegiatan bagi Guru: (1) Identifikasi Kompetensi Guru; (2) Workshop Prapenelitian Pendidikan; (3) Pendampingan kegiatan Plan; (4) Pendampingan Pelaksanaan PTK Tahap Do; (5) Pendampingan Tahap See atau Refleksi Pembelajaran; (6) Pendampingan Analisis data Penelitian dan Penulisan Laporan PTK; dan (7) Evaluasi Pelaksanaan Kegiatan. Kegiatan pengabdian dilaksanakan dengan 2 tahap dengan peserta pada tahap I adalah 32 orang $(57,14 \%)$, sedangkan pada tahap II adalah 38 orang $(67,86 \%)$ dengan jumlah total guru 56 orang. Target dalam kegiatan ini secara keseluruhan tercapai dengan baik, yaitu hampir $75 \%$ peserta yang mengikuti kegiatan pelatihan sudah memiliki laporan yang mana masih membutuhkan bimbingan lanjutan untuk semakin menyempurnakan laporan yang sudah dibuat
\end{abstract}

A B S T R A C T

Lesson Study is a form of activity for enhancing teaching quality with the model Plan, Do, See (reflect). The outcome objectives of this community service were : (1) to develop an innovative teaching strategy; (2) to produce a high quality classroom action research and (3) to improve soft skill in scientific publication. The methods used in this beginner lecturer community service program were training, guiding, individual task, and classroom action research practice. Specifically, the activities for the teachers were (1) identifying the teachers' competencies; (2) running a pre-research workshop education ; (3) giving an assistance in activity planning ; (4) giving an assistance in doing stage Do of the classroom action research ; (5) giving an assistance in doing stage See or teaching reflection ; (6) giving an assistance in analyzing research data and writing a classroom action research report; and (7) evaluating the activities implementation. The community service activity was conducted in two stages with 32 participants $(57.14 \%)$ at the the first stage and 38 participants $(67.86 \%)$ at the second stage with the total number of the teachers was 56 . The objective of this activity, on the whole, was attained well, i.e, almost $75 \%$ of the particants who joined the training had produced reports, but they still need to be assisted in improving the quality of the reports that they wrote.

\footnotetext{
* Corresponding author.

E-mail addresses: fajarsh89@gmail.com (Fajar Surya Hutama)
} 



\section{Pendahuluan}

Peneyelenggaraan pendidikan, senantiasa menghadapi permasalahan dalam berbagai aspeknya, guru dan pembelajaran. Para ahli pendidikan terus mencari dan mengujicobakan penemuanpenemuannya sebagai solusi untuk mengatasi masalah tersebut. Bagaimana upaya untuk menemukan cara yang terbaik guna mencapai pendidikan yang bermutu dalam rangka menciptakan sumber daya manusia yang handal dari segi bidang akademis, mampu bersaing di era globalisasi, menjadi manusia yang cerdas, berkepribadian utuh, santun dan berahlak mulia (Rasmiyah,2012). Salah satu kompetensi yang harus dimiliki oleh guru dalam pengelolaan pembelajaran adalah kompetensi pedagogik yang telah ditetapkan dalam Peraturan Pemerintah Republik Indonesia Nomor 74 Tahun 2008. Berdasarkan Peraturan Pemerintah Republik Indonesia Nomor 19 Tahun 2005 tentang Standar Pendidik dan Tenaga Kependidikan yang dinyatakan bahwa kompetensi pedagogik adalah kemampuan mengelola pembelajaran peserta didik yang meliputi pemahaman terhadap peserta didik, perancangan dan pelaksanaan pembelajaran, evaluasi hasil belajar, dan pengembangan peserta didik untuk mengaktualisasikan berbagai potensi yang dimilikinya.

Kemampuan guru dalam pengelolaan pembelajaran terdapat dalam Peraturan Menteri Pendidikan Nasional Republik Indonesia Nomor 16 Tahun 2007 tentang Standar Kompetensi Akademik dan Kompetensi Guru yang meliputi kompetensi pedagogik adalah (1) menguasai karakteristik peserta didik dari aspek fisik, moral, spiritual, sosial, kultural, emosional, dan intelektual, (2) menguasai teori belajar dan prinsip-prinsip pembelajaran yang mendidik, (3) mengembangkan kurikulum yang terkait dengan mata pelajaran yang diampu, (4) menyelenggarakan pembelajaran yang mendidik, (5) memanfaatkan teknologi informasi dan komunikasi untuk kepentingan pembelajaran, (6) memfasilitasi pengembangan potensi peserta didik untuk mengaktualisasikan berbagai potensi yang dimiliki, (7) berkomunikasi secara efektif, empati, dan santun dengan peserta didik, (8) menyelenggarakan penilaian dan evaluasi proses dan hasil belajar, (9) memanfaatkan hasil penilaian dan evauasi untuk kepentingan pembelajaran, dan (10) melakukan tindakan reflektif untuk peningkatan kualitas pembelajaran.

Anggota Kelompok Kerja Guru (KKG) Gugus Sekolah (GUSEK) 2 Tenggarang Kabupaten Bondowoso terdiri dari sejumlah guru dari 10 Sekolah Dasar Negeri (SDN) di Kecamatan Tenggarang Kabupaten Bondowoso, yaitu (1) SDN Pekalangan 1; (2) SDN Pekalangan 2; (3) SDN Pekalangan 3; (4) SDN Kasemek 1; (5) SDN Kasemek 2; (6) SDN Dawuhan; (7) SDN Gebang; (8) SDN Tangsil Kulon 1; (9) SDN Tangsil Kulon 2; (10) SDN Lojajar, Jumlah keseluruhan anggota KKG 2 Tenggarang adalah 62 orang guru yang terdiri dari 56 Guru PNS dan 6 Guru Non PNS. Sebagai seorang guru PNS, maka anggota guru PNS KKG 2 Tenggarang diwajibkan untuk melaksanakan pengembangan dan pembinaan baik profesi maupun karier. Berdasarkan analisis data profil anggota guru PNS dan wawancara dengan ketua KKG 2 Tenggarang didapatkan beberapa persoalan yang dialami oleh guru dan membutuhkan pendampingan penyelesaian persoalan yang lebih "komprehensif dan berkelanjutan".

Analisis data profil Guru PNS anggota KKG 2 Tenggarang terhadap jabatan dan golongan didapatkan 10\% (6 dari 60) Guru Pertama III/a, 10\% (6 dari 60) Guru Pertama III/b, 5\% (3 dari 60) Guru Muda III/c, 18,3\% (11 dari 60) Guru Madya IV/a, dan 26,7\% (16 dari 60) Guru Madya IV/b. Berdasarkan jabatan dan golongan yang dimiliki, maka guru diwajibkan untuk melaksanakan beban tugas utama guru yaitu melaksanakan pembelajaran dan pengembangan keprofesian berkelanjutan (PKB). Unsur PKB adalah pengembangan diri dan publikasi ilmiah, dan/atau pengembangan karya inovatif. Indikator keterlaksanaan kewajiban tugas utama guru untuk unsur PKB adalah melakukan penelitian tindakan kelas (PTK) dan mempublikasikan hasil penelitian pada jenis publikasi ilmiah.

Hasil wawancara kepada beberapa anggota KKG 2 Tenggarang menunjukkan bahwa hanya beban tugas melaksanakan pembelajaran yang dapat dilaksanakan secara optimal oleh guru, sedangkan untuk tugas PKB tentang pelaksanaan PTK dan publikasi ilmiah masih banyak terdapat permasalahan yang membutuhkan adanya solusi. Guru jarang, dan bahkan terdapat guru yang tidak pernah melakukan PTK. Selain itu, guru tidak pernah melaksanakan publikasi ilmiah, baik di jurnal ilmiah nasional ataupun prosiding seminar nasional. Laporan PTK sering dibuat jika ada keperluan yang mendesak, yaitu adanya tinjauan penilaian kinerja oleh pengawas pendidikan dasar atau kebutuhan kenaikan pangkat. Meskipun demikian, hasil penilaian kualitas laporan PTK yang telah dibuat oleh guru sering mendapatkan nilai angka kredit yang kurang maksimal.

Selain guru diwajibkan untuk pengembangan dan pembinaan profesi, guru juga diwajibkan untuk melaksanakan pengembangan dan pembinaan karier melalui kenaikan pangkat dan jabatan. Persyaratan minimal usulan kenaikan pangkat adalah minimal telah 2 tahun dalam pangkat terakhir (Pasal 16, Perbersama Mendiknas dan Kepala BKN No. 14, 2010), namun berdasarkan data tahun SK kenaikan pangkat guru PNS terdapat beberapa guru yang terlambat mengusulkan kenaikan pangkat dan juga terdapat guru yang masih memiliki kesempatan 1 tahun lagi untuk mempersiapkan angka kredit kenaikan 
pangkat. Kondisi ini menunjukkan bahwa guru tersebut ternyata belum memiliki angka kredit tentang publikasi ilmiah.

Berdasarkan hasil wawancara kepada beberapa guru anggota KKG 2 Tenggarang tentang penyebab guru jarang atau tidak pernah melakukan Penelitian Tindakan Kelas (PTK) adalah rendahnya pemahaman dan motivasi guru dalam pelaksanaan PTK masih rendah. Pemahaman guru tentang PTK lemah pada: (1) penentuan ide prioritas masalah yang dapat digunakan sebagai masalah PTK; (2) pemilihan alternatif solusi masalah sebagai rencana tindakan perbaikan pembelajaran; (3) rincian pelaksanaan rencana perbaikan pembelajaran di kelas; (4) perencanaan pengambilan data; (5) pelaksanaan penelitian dalam pembelajaran di kelas; dan (6) pengolahan data hasil penelitian. Motivasi guru yang rendah dalam melaksanakan PTK disebabkan oleh pandangan bahwa jika selain guru melaksanakan pembelajaran, juga harus melakukan penelitian, maka dalam pengambilan data penelitian sulit dilakukan, sehingga tidak dapat fokus dalam mengajar. Selain itu, Metode ilmiah penelitian dianggap guru sebagai serangkaian kegiatan yang rumit pelaksanaannya, butuh persiapan yang menguras tenaga, dan jika kegiatan kerja ilmiah penelitian dikolaborasikan pada tugas utama guru dalam pembelajaran, maka dapat mengganggu proses pembelajaran di kelas.

Hasil wawancara juga menunjukkan bahwa persoalan utama dalam masalah kenaikan pangkat adalah pemberlakuan aturan kenaikan pangkat yang mewajibkan guru membuat karya tulis ilmiah dan dipublikasikan pada forum (prosiding) ataupun jurnal ilmiah. Meskipun terdapat beberapa guru yang memiliki laporan hasil penelitian PTK dan digunakan untuk usulan kenaikan pangkat, namun angka kredit yang diberikan oleh Tim Asesor kurang dari nilai maksimal. Hal ini disebabkan oleh minimnya pengetahuan guru tentang metodologi penelitian ilmiah dan minimnya pengalaman guru dalam penulisan laporan penelitian ilmiah, sehingga berdampak pada rendahnya kualitas hasil penelitian dan penulisan laporan hasil penelitian. Sebenarnya pemerintah telah mencoba mengatasi masalah guru dengan membuat peraturan terbaru tentang kewajiban guru tiap tahun untuk menyusun Sasaran Kinerja Pegawai (SKP) dan di akhir tahun terdapat evaluasi terhadap target pencapaian SKP. Meskipun demikian, persoalan guru masih tetap terjadi pada pencapaian target beban tugas guru pada pelaksanaan PTK dan publikasi hasil penelitian.

Berdasarkan kesepakatan tim pengabdian dengan ketua KKG 2 Tenggarang dihasilkan bahwa prioritas persoalan yang perlu dicarikan solusi adalah: (1) Metodologi Penelitian Tindakan Kelas (PTK); (2) Penulisan laporan hasil PTK; dan (3) Publikasi hasil penelitian pada jurnal nasional atau prosiding seminar nasional

\section{Metode}

Metode pelaksanaan program pengabdian ini adalah pelatihan, pembimbingan, tugas mandiri, dan praktek penelitian di kelas. Secara terperinci kegiatan bagi Guru anggota KKG GUSEK 2 Tenggarang Bondowoso sebagai berikut.

1. Identifikasi Kompetensi Guru

Tim pelaksana program bersama Ketua KKG mengidentifikasi kompetensi guru. Identifikasi dilakukan berdasarkan bidang keilmuan guru, tugas guru sebagai guru kelas, dan pengalaman guru mengajar. Hasil identifikasi digunakan sebagai pertimbangan kriteria pengelompokan guru menjadi kelompok peneliti atau Research Group. Target luaran kegiatan ini adalah Tim pelaksana mendapatkan peta kompetensi guru Anggota KKG. Guru anggota KKG dikelompokan sebagai Research Group. Research Group terdiri dari 5 anggota (tiap sekolah diwakili oleh satu guru)

2. Workshop Prapenelitian Pendidikan

Peserta Workshop adalah seluruh Guru Anggota KKG GUSEK 2 Tenggarang Bondowoso. Metode pelaksanaan workshop ini adalah ceramah, diskusi, dan penugasan. Kegiatan ini bertujuan untuk membekali peserta, baik pengetahuan dan keterampilan, untuk kegiatan penelitian dan pembelajaran di kelas. Kegiatan Workshop diawali dengan pemaparan oleh Tim pelaksanan pengabdian tentang: (a) Isu dan Tantangan Pembelajaran pada Jenjang Sekolah Dasar; (b) Lesson Study sebagai Peningkatan Kualitas Pembelajaran; (c) Pembelajaran Inovatif Berbasis Penelitian; (d) Metodologi Penelitian Pendidikan; (e) Perencanaan, Pelaksanaan, dan Analisis Data Hasil Penelitian Tindakan Kelas (PTK); dan (f) Publikasi Hasil Penelitian.

Target luaran yang dihasilkan kegiatan ini adalah guru memiliki pengetahuan tentang pembelajaran inovatif, serta tiap Research Group memiliki ide masalah untuk PTK, membuat proposal PTK, perangkat perbaikan pembelajaran, draft instrumen pengambilan data penelitian. Target luaran ini dilaksanakan dengan metode penugasan dan akan dibahas kembali saat kegiatan Plan.

3. Pendampingan kegiatan Plan 
Kegiatan ini dilaksanakan sebagai tahapan Plan dalam Lesson Study, bertujuan untuk finalisasi instrumen penelitian dan perangkat pembelajaran. Kegiatan ini dilaksanakan dengan cara Tim pelaksana pengabdian bersama seluruh Guru anggota KKG berkumpul dan tiap Research Group mempresentasikan instrumen PTK serta perangkat pembelajaran. Tim pelaksana memberikan arahan alur pelaksanaan kegiatan Plan dan memberikan saran terhadap presentasi masing-masing Research Group. Anggota Researh Group yang lain juga dapat memberikan saran berdasarkan pengetahuan dan pengalaman yang dimiliki. Melalui kegiatan ini diharapkan terjadi diskusi antar anggota Research Group, sehingga dapat digunakan sebagai rujukan perbaikan dan pemantapan terhadap instrumen penelitian dan perangkat pembelajaran.

Target luaran kegiatan ini adalah seluruh Research Group memiliki kesiapan, baik instrumen penelitian, perangkat pembelajaran, dan mental dalam melaksanakan PTK. Tahapan ini juga akan memilih guru Model, yaitu guru yang melaksanakan perangkat pembelajaran di kelas.

4. Pendampingan Pelaksanaan PTK: Tahap Do

Kegiatan ini dilaksanakan sebagai tahapan Do dalam Lesson Study. Kegiatan ini bertujuan untuk implementasi perangkat pembelajaran yang telah dibuat oleh masing-masing Research Group, Pelaksanaan PTK, dan pengambilan data penelitan. Pelaksanaan penelitian dilaksanakan dengan cara Open Class, yaitu Tim pelaksana pengabdian dan seluruh Guru anggota KKG GUSEK 2 Tenggarang Bondowoso hadir sebagai Observer dalam pelaksanaan pembelajaran di kelas yang dilakukan oleh guru model.

Sebelum pelaksanaan Open Class, Tim pelaksana memberikan pembekalan tentang alur kegiatan, tujuan, rincian tugas Observer pada pelaksanaan Open Class. Tugas Observer selain mengamati proses pembelajaran di kelas, juga untuk membantu pengambilan data penelitian. Kegiatan Open Class dilaksanakan di seluruh sekolah anggota Research Group. Pelaksanaan PTK untuk siklus berikutnya dilaksanakan juga secara Open Class, namun anggota Observer hanya wajib diperuntukkan bagi anggota Research Group, namun juga tidak tertutup bagi guru lain yang berminat untuk menjadi Obsever.

Target luaran yang dihasilkan dalam kegiatan ini adalah guru memiliki keterampilan dalam pelaksanaan pembelajaran inovatif di kelas, membangun keterampilan bekerjasama antar sesama guru, keterampilan melaksanakan penelitian, dan keterampilan pengambilan data penelitian. Hasil observasi dapat digunakan oleh Research Group sebagai data tambahan dalam pelaksanaan penelitian.

5. Pendampingan Tahap See atau Refleksi Pembelajaran

See merupakan tahap lanjutan kegiatan Lesson Study, kegiatan ini dilaksanakan dengan cara merefleksikan pengalaman Guru Model dan temuan-temuan proses pembelajaran oleh Observer. Pelaksanaan See diawali dengan pembekalan oleh Tim pelaksana tentang alur kegiatan, tujuan, dan etika penyampaian gagasan baik oleh Guru Model maupun Observer.

Target luaran kegiatan ini adalah membangun keterampilan guru mengungkapkan pendapat, keterampilan berargumentasi, desain pembelajaran inovatif yang sesuai dengan materi ajar. Hasil kegiatan See dapat digunakan Research Group sebagai data pendukung analisis dan pembahasan data penelitian, serta sebagai acuan pelaksanaan perbaikan pembelajaran siklus berikutnya.

6. Pendampingan Analisis data Penelitian dan Penulisan Laporan PTK

Kegiatan ini dilaksanakan dengan metode pendampingan terhadap analisis data hasil penelitian untuk menyimpulkan hasil PTK, penulisan laporan PTK, penulisan hasil PTK ke dalam artikel penelitian, dan publikasi artikel PTK. Pelaksanaan kegiatan ini membutuhkan pendampingan dan monitoring yang cukup intensif, sehingga dalam pendampingan dilaksanakan tutorial secara bertahap dan berkelanjutan. Tiap pertemuan tutorial, Tim pelaksana pengabdian memberikan penugasan kepada Research Group dan didiskusikan saat pertemuan tutorial hingga seluruh Research Group telah membuat artikel yang siap untuk publikasi.

Target luaran kegiatan ini adalah guru memiliki keterampilan dalam menganalisis data hasil penelitian, menulis karya tulis ilmiah, serta Research Group memiliki artikel ilmiah hasil penelitian yang siap untuk publikasi. Publikasi hasil penelitian dilaksankan pada Prosiding seminar nasional pendidikan atau jurnal pendidikan ber-ISSN.

7. Evaluasi Pelaksanaan Kegiatan

Kegiatan ini bertujuan untuk mengukur keberhasilan tujuan pelaksanaan kegiatan pengabdian. Indikator keberhasilan dilihat berdasarkan pada: (a) ide masalah pembelajaran yang digunakan dalam PTK oleh Research Group; (b) Perangkat pembelajaran inovatif; (c) Aktivitas pelaksanaan PTK; (d) Ketercapaian target pelaksanaan PTK yang ditetapkan oleh Research Group; (e) Kualitas artikel hasil penelitian. Target luaran kegiatan ini juga digunakan untuk rencana tindak lanjut kegiatan Guru anggota KKG setelah kegiatan pengabdian selesai. Oleh karena itu meskipun kegiatan pengabdian telah berakhir, guru-guru masih tetap dapat melanjutkan kegiatan PTK dan Lesson Study, bahkan lingkup kegiatan 
peruntukannya juga dapat lebih diluaskan dengan anggota seluruh guru di Kecamatan Tenggarang Kabupaten Bondowoso

\section{Hasil dan pembahasan}

Kegiatan pengabdian kepada masyarakat ini dilaksanakan oleh 2 orang Dosen FKIP. Kegiatan diawali dengan adanya temuan permasalahan yang ada di Kelompok Kerja Guru (KKG) Gugus Sekolah (GUSEK) 2 Tenggarang Kabupaten Bondowoso terkait dengan masih sedikitnya hasil karya guru dalam bidang penelitian. Berdasarkan kondisi tersebut, maka Dosen yang ditugaskan untuk memberikan pelatihan dan pendampingan sebagai berikut. 1. Fajar Surya Hutama, S.Pd, M.Pd (Ketua), dan 2. Agustiningsih, S.Pd, M.Pd (Anggota Pelaksana)

Kegiatan yang terlaksana meliputi kegiatan: (1) pemaparan mengenai materi terkait research group berbasis lesson study pembelajaran; (2) pelaksanaan tahap plan melalui diskusi antar anggota research group, sehingga dapat digunakan sebagai rujukan perbaikan dan pemantapan terhadap instrumen penelitian dan perangkat pembelajaran; (3) pendampingan untuk tahap do yang bertujuan agar guru memiliki keterampilan dalam pelaksanaan pembelajaran inovatif di kelas, membangun keterampilan bekerjasama antar sesama guru, keterampilan melaksanakan penelitian, dan keterampilan pengambilan data penelitian. Hasil observasi dapat digunakan oleh research group sebagai data tambahan dalam pelaksanaan penelitian; (4) Pendampingan tahap see atau refleksi pembelajaran yang bertujuan untuk membangun keterampilan guru mengungkapkan pendapat, keterampilan berargumentasi, desain pembelajaran inovatif yang sesuai dengan materi ajar; (5) Pendampingan analisis data penelitian dan penulisan laporan PTK yang bertujuan agar guru memiliki keterampilan dalam menganalisis data hasil penelitian, menulis karya tulis ilmiah, serta Research Group memiliki artikel ilmiah hasil penelitian yang siap untuk publikasi; dan (6) evaluasi pelaksanaan kegiatan yang bertujuan untuk mengukur keberhasilan tujuan pelaksanaan kegiatan pengabdian.

Pada tahap awal kegiatan dilakukan sosialisasi dan koordinasi dengan Ketua KKG GUSEK 2 Tenggarang untuk mendiskusikan tentang rundown acara kegiatan, menentukan lokasi pelaksanaan kegiatan, waktu pelaksanaan, jumlah peserta (guru) yang akan mengikuti kegiatan pelatihan dan pihak yang harus diundang yang meliputi Kepala Unit Pelaksana Teknis Dinas Pendidikan dan Kebudayaan (UPTD) Kecamatan Tenggarang, Ketua Kelompok Kerja Kepala Sekolah (KKKS) Kecamatan Tenggarang dan Pengawas TK/SD Kecamatan Tenggarang. Hasil koordinasi menghasilkan kesepakatan bahwasannya kegiatan tahap I akan dilaksanakan pada hari Rabu tanggal 18 Oktober 2017. Waktu pelaksanaan tersebut diambil dengan pertimbangan bahwa baik Dosen maupun Guru dapat hadir pada waktu tersebut, dan yang lebih penting lagi pelatihan yang dilaksanakan tidak akan mengganggu aktivitas akedemik.

Kegiatan yang dilakukan pada tahap I ini adalah pemaparan materi pelatihan sebagai penyegaran informasi untuk para peserta pelatihan. Materi yang disampaikan dalam pelatihan ini yaitu: (a) Isu dan Tantangan Pembelajaran pada Jenjang Sekolah Dasar; (b) Lesson Study sebagai Peningkatan Kualitas Pembelajaran; (c) Pembelajaran Inovatif Berbasis Penelitian; (d) Metodologi Penelitian Pendidikan; (e) Perencanaan, Pelaksanaan, dan Analisis Data Hasil Penelitian Tindakan Kelas (PTK); dan (f) Publikasi Hasil Penelitian.

Pada kegiatan ini dari jumlah 62 guru yang terdata di awal, ternyata terdapat 4 orang guru yang sudah pensiun, 1 orang guru meninggal dunia, dan 1 orang guru lagi sudah dimutasi. Berdasarkan kondisi tersebut, maka jumlah peserta yang terdata seharusnya ada 56 orang. Kegiatan tahap 1 dihadiri sebanyak 32 guru. Kondisi ini terjadi, karena memang tidak memungkinkan untuk semua peserta hadir di kegiatan. Hal ini dikarenakan menyangkut dengan proses belajar mengajar guru yang ada di SD. Apabila semua guru di satu SD hadir semuanya, maka proses pembelajaran yang ada di SD harus diliburkan, dan kondisi tersebut justru menyalahi aturan pelaksanaan pembelajaran.

Pemaparan materi yang diberikan dalam pelatihan ini diawali dengan materi "Isu dan Tantangan Pembelajaran pada Jenjang Sekolah Dasar". Materi ini disampaikan untuk memberikan pemahaman awal pada guru-guru tentang hal-hal/kondisi yang bisa menjadi orientasi guru dalam menyusun sebuah karya penelitian. Materi selanjutnya adalah tentang "Lesson Study sebagai Peningkatan Kualitas Pembelajaran". Materi ini disampaikan agar para guru memahami tentang apa itu lesson study, bagaimana pelaksanaannya, dan juga apa manfaatnya. Untuk materi terakhir dari kegiatan ini yaitu tentang Pembelajaran Inovatif Berbasis Penelitian dan Metodologi Penelitian Pendidikan. Materi ini disampaikan agar para guru memiliki pemahaman yang tepat tentang penelitian yang akan dilakukan.

Pada tahap 1 ini, setelah pemaparan materi selesai, maka dilanjutkan dengan pelaksanaan tahan plan sebagai bagian dari lesson study melalui diskusi antar anggota research group, yang mana anggota research group ini adalah guru-guru dari $1 \mathrm{SD}$, agar dalam pelaksanaan tahap "do" berjalan lebih maksimal. Kegiatan dilaksanakan dengan cara Tim pelaksana pengabdian bersama seluruh Guru anggota 
KKG berkumpul dan tiap research group mempresentasikan permasalahan sebagai dasar penyusunan instrumen serta perangkat pembelajaran.

Dalam pelaksanaan presentasi terjadi sedikit kendala yaitu speaker terkadang tidak berfungsi, sehingga dalam pemaparan materi terkadang langsung disampaikan tanpa menggunakan speaker, akibatnya suara saat pemaparan materi menurut beberapa peserta pelatihan kurang keras. Dalam pemaparan materi tidak menggunakan power point, namun para peserta langsung memaparkan hasil diskusi dalam research groupnya. Tim pelaksana memberikan saran terhadap presentasi masing-masing research group. Anggota researh group yang lain juga memberikan saran berdasarkan pengetahuan dan pengalaman yang dimiliki. Melalui kegiatan terjadi diskusi antar anggota research group, sehingga dapat digunakan sebagai rujukan perbaikan dan pemantapan terhadap instrumen penelitian dan perangkat pembelajaran yang telah dibuat.

Target dalam kegiatan plan tercapai dengan baik, yaitu setiap peserta memiliki kesiapan, baik instrumen penelitian, perangkat pembelajaran, dan mental dalam melaksanakan PTK. Setiap research group juga sudah memilih guru Model, yaitu guru yang melaksanakan perangkat pembelajaran di kelas. Saat sesi diskusi dan presentasi, para guru sudah banyak yang memiliki ide untuk PTK yang hendak disusun, dari 32 guru yang hadir, 20 orang diantaranya sudah memiliki ide untuk melaksanakan PTK. dan menyampaikan idenya serta didiskusikan dengan pemateri. Kegiatan tahap I ini diakhiri dengan membuat komitmen bersama, bahwasannya untuk tahap selanjutnya peserta yang hadir diharapkan sudah memiliki permasalahan dalam kelas yang akan diselesaikan melalui research group berbasis lesson study dengan PTK sebagai rancangan penelitiannya.

Untuk tahap II setelah dilakukan koordinasi dengan Ketua KKG GUSEK 2 Tenggarang Bapak Eko Cahya Rahmad, S.Pd, menghasilkan kesepakatan bahwasannya kegiatan tahap II akan dilaksanakan pada hari Sabtu tanggal 18 Nopember 2017. Waktu pelaksanaan tersebut diambil dengan pertimbangan bahwa baik Dosen maupun Guru dapat hadir pada waktu tersebut, dan yang lebih penting lagi kegiatan tidak mengganggu aktivitas pembelajaran.

Kegiatan tahap 1 ini dihadiri sebanyak 38 guru dari jumlah peserta sebanyak 56 orang. Jumlah peserta ini lebih banyak 6 orang guru daripada tahap I, hal ini dikarenakan, apabila semua guru hadir, maka aktivitas pembelajaran di SD harus diliburkan, dan tentunya kegiatan yang dilakukan justru bisa berdampak kurang baik.

Pemaparan materi yang diberikan dalam tahap II merupakan lanjutan dari tahap I, karena apabila semua materi disampaikan dalam tahap I, waktu yang diperlukan akan lama, dan peserta justru tidak tertarik dengan kegiatan. Materi awal yang disampaikan terkait dengan "Metodologi Penelitian Pendidikan" yang bertujuan agar para guru memahami tentang proses yang harus dilaksanakan dalam sebuah peneliltian pendidikan yang dalam hal ini fokus pada PTK. Materi kedua yaitu tentang "Perencanaan, Pelaksanaan dan Observasi serta Analisis Data Hasil PTK". Pada materi ini sekilas kegiatan yang harus dilakukan dalam rangkaian kegiatan PTK sangat sesuai apabila ditearapkan dengan kegiatan lesson study. Materi akhir adalah tentang "Publikasi Hasil Penelitian". Pada tahap ini adalah tahap akhir yang mana semua peserta harapannya dapat memiliki artikel yang bisa dipublikasikan dan bisa bermanfaat untuk karir keprofesionalan guru.

Pada tahap II ini, setelah pemaparan materi selesai, maka dilanjutkan dengan pelaksanaan tahap do sebagai bagian dari lesson study. Tahap do ini harus dilaksanakan para peserta dengan berpraktik di SD yang merupakan tempatnya mengajar dan juga tempat munculnya permsalahan yang hendak diselesaikan, sehingga pada tahap ini kegiatan yang dilakukan adalah dengan memberikan masukan terhadap perangkat pembelajaran yang hendak digunakan oleh para guru dalam melaksanakan kegiatan. Tahap do sendiri dilakukan dengan memberikan pendampingan pada setiap anggota reseacrh group saat melaksanakan pembelajaran di kelas.

Selain tahap do yang dilakukan dengan melakukan pendampingan pada guru, pendampingan juga dilakukan untuk tahap see atau refleksi pembelajaran dan juga tahap pendampingan analisis data penelitian dan penulisan laporan PTK. Evaluasi pelaksanaan kegiatan yang bertujuan untuk mengukur keberhasilan tujuan pelaksanaan kegiatan pengabdian dilakukan secara internal oleh tim pelaksana pengabdian, Ketua KKG GUSEK 2 Kecamatan Tenggarang dan Perwakilan dari setiap research group.

Target dalam kegiatan ini secara keseluruhan tercapai dengan baik, yaitu hampir $75 \%$ peserta yang mengikuti kegiatan pelatihan sudah memiliki laporan yang mana masih membuthkan bimbingan lanjutan untuk semakin menyempurnakan laporan yang sudah dibuat. Kendala yang dihadapi dalam kegiatan ini diantaranya beberapa orang guru datang terlambat saat kegiatan, kondisi cukup mengganggu, namun demikian guru yang terlambat hadir dapat menyesuaikan diri dengan baik.

Proses kegiatan diikuti dengan sangat antusias oleh peserta pelatihan, meskipun ada beberapa peserta yang terlambat. Diskusi dan masukan yang diberikan oleh peserta sangat mendukung proses 
pelatihan. Antusiasme para peserta pelatihan dapat dilihat dari keseksamaannya dalam memperhatikan dan mengikuti pelatihan.

Antusiasme para peserta pelatihan merupakan modal yang baik untuk keberhasilan pelatihan secara khusus dan berdampak pada peningkatan kualitas pembelajaran yang dilakukan oleh guru secara umum, yang tercapai melalui pelaksanaan penelitian yang dilakukan. Para guru yang ada dalam KKG GUSEK 2 Kecamatan Tenggarang merupakan SDM yang diharapkan dapat terus berkarir dan berkarya, tidak hanya lewat pembelajaran, namun juga penelitian, sehingga pada akhirnya dapat berimbas positif terhadap kualitas pendidikan, khususnya di Kabupaten Bondowoso.

Pertanyaan yang disampaikan oleh peserta pelatihan adalah sebagai berikut: (1) bagaimana proses untuk kami dapat menerbitkan tulisan kami ke dalam sebuah jurnal?; (2) Dalam pembelajaran biasanya ada siswa yang aktif bertanya, namun ketika dites ternyata nilainya tidak lebih baik dari siswa yang lain, bagaimana menyikapi hal tersebut?; dan (3) Bagaimanakah kami dapat membuat sebuah penelitian yang baik, padahal waktu yang kami gunakan untuk membimbing anak-anak didik kami sudah sangat terbatas?

Jawaban dari pertanyaan-pertanyaan para guru tersebut secara umum sebagai berikut: (1) Untuk dapat menerbitkan tulisan Bapak/Ibu ke dalam sebuah jurnal tidaklah sulit, apabila laporan penelitian Bapak/Ibu ini selesai, selanjutnya tinggal menuliskannya dalam format jurnal yang hendak Bapak/lbu tuju dan mengirimkan pada pengelola jurnal tersebut. Terkait dengan hal tersebut, kami akan melakukan pendampingan pada Bapak/Ibu hingga artikel Bapak/Ibu dapat terbit pada sebuah jurnal. Selain itu Bapak/Ibu dapat menerbitkannya di tempat kami yaitu Program Studi Pendidikan Guru Sekolah Dasar (PGSD) Fakultas Keguruan dan Ilmu Pendidikan (FKIP) Universitas Jember (UNEJ), karena kami memiliki jurnal untuk guru-guru SD yaitu Jurnal ilmu Pendidikan Sekolah Dasar (JIPSD), yang mana jurnal kami juga sudah ber-ISSN; (2) Ini pentingnya kolaborasi dalam PTK, guru bisa fokus dalam pelaksanaan pembelajaran, sedangkan kolaborator yang dalam hal ini anggota research group dapat membantu guru untuk mencatat berbagai temuan ataupun hal-hal menarik yang terjadi selama pelaksanaan penelitian, misalnya aktivitas siswa baik saat bekerja kelompok maupun saat menyelesaikan tugas secara mandiri; dan (3) Untuk dapat membuat sebuah penelitian yang baik, tentunya diperlukan pengorbanan, terkait dengan hal tersebut, kami akan mendampingi Bapak/Ibu dalam penyusunannya, karena memang itulah tugas kami dalam kegiatan ini. Bapak/Ibu tidak perlu risau dengan biaya, karena kami selaku tim pelaksana sudah berkomitmen dari awal untuk membantu Bapak/Ibu.

Seorang guru profesional harus memiliki kompetensi dalam melakukan penelitian. Tuntutan kompetensi dalam bidang penelitian dan publikasi ilmiah hasil penelitian semakin penting bagi seorang Guru sejak ditetapkan Pedoman Pengembangan Keprofesionalan Berkelanjutan atau yang dikenal dengan PKB (Kemendikbud, dalam Masyhud, 2015:1). Berdasarkan pada hal ini, beberapa anggota KKG GUSEK 2 Tenggarang menunjukkan bahwa hanya beban tugas melaksanakan pembelajaran yang dapat dilaksanakan secara optimal, sedangkan untuk tugas pengembangan keprofesian berkelanjutan (PKB) tentang pelaksanaan PTK dan publikasi ilmiah masih banyak terdapat permasalahan yang membutuhkan adanya solusi. Guru jarang, dan bahkan terdapat guru yang tidak pernah melakukan PTK. Selain itu, guru tidak pernah melaksanakan publikasi ilmiah, baik di jurnal ilmiah nasional ataupun prosiding seminar nasional. Laporan PTK sering dibuat jika ada keperluan yang mendesak, yaitu adanya tinjauan penilaian kinerja oleh pengawas pendidikan dasar atau kebutuhan kenaikan pangkat. Meskipun demikian, hasil penilaian kualitas laporan PTK yang telah dibuat oleh guru sering mendapatkan nilai angka kredit yang kurang maksimal.

Alternatif solusi penyelesaian persoalan yang dihadapi mitra adalah program kegiatan Research Group berbasis Lesson Study Pembelajaran. Lesson Study adalah bentuk kegiatan untuk peningkatan kualitas pembelajaran dengan model kegiatan Plan, Do, See (refleksi). Kegiatan Lesson Study dilaksanakan oleh beberapa guru dan tujuan hasil luaran adalah merencanakan dan memecahkan masalah pembelajaran di kelas secara kolaboratif (Cajkler, 2014; Halvorsen, 2013; Waris, 2014). Esensi pelaksanaan PTK identik dengan tujuan hasil luaran pelaksanaan Lesson Study, maka strategi pelaksanaan PTK dapat dikolaborasikan dengan Lesson Study. Oleh karena itu kegiatan Research Group berbasis Lesson Study pembelajaran sangat tepat untuk diterapkan di KKG GUSEK 2 Kecamatan Tenggarang Kabupaten Bondowoso.

Seorang guru wajib untuk melakukan PTK karena hal tersebut berkaitan dengan profesionalisme, praktik pembelajaran di kelas, kontrol sosial terhadap guru, serta kemanfaatan penelitian pendidikan. Dari segi profesionalisme, PTK yang dilakukan guru dipandang sebagai satu unjuk kerja seorang guru profesional, karena studi sistematik yang dilakukan terhadap diri sendiri (guru) dianggap sebagai tanda (hallmark) dari pekerjaan guru yang profesional (Wardhani \& Wihardit, 2011:1.11).

Pelaksanaan kegiatan pengabdian kepada masyarakat dengan sasaran para guru KKG GUSEK 2 Kecamatan Tenggarang berjalan cukup sukses dan lancar, karena tujuan kegiatan pengabdian yang telah direncanakan sebelumnya telah memenuhi target. Pelaksanaan pelatihan ini dinilai cukup berhasil, karena 
berdasarkan jumlah kehadiran peserta, peserta yang hadir sudah lebih dari 50\%. Kondisi ini menunjukkan tingginya komitmen dan semangat para peserta untuk dapat melaksanakan PTK melalui kegiatan reseach group berbasis lesson study dan dapat membuat sebuah artikel PTK. Pengabdian ini juga didukung oleh penelitian Murtisal (2016) yang menyatakan kompetensi pedagogik guru biologi melalui implementasi pembelajaran berbasis Lesson Study di SMA Negeri 11 Banda Aceh dan MAN 3 Banda Aceh berlangsung baik dengan nilai kompetensi pedagogik guru model SMA Negeri 11 Banda Aceh 99\% (kategoriSangat Baik) dan guru model MAN 3 Banda Aceh 92\% (kategoriSangat Baik). Selain itu Trsinayanti 2014 menyatakan terdapat pengaruh signifikan pada pelaksanaan diklat lesson study terhadap peningkatan kompetensi pedagogik guru Sains SMP Negeri 1 Singaraja.

Meskipun pelaksanaan kegiatan secara keseuruhan dapat dikatakan berhasil, namun demikian dari hasil yang diperoleh pendampingan yang dilakukan masih perlu dilakukan selesainya kegiatan. Kondisi ini terjadi karena ada beberapa anggota research group yang masih belum memiliki ide untuk melakukan PTK. Selain itu, kendala yang utama adalah, para guru baru mau melakukan PTK apabila mereka terdesak dengan kepentingan untuk kenaikan pangkat, sehingga dengan kondisi seperti ini, kegiatan pendampingan perlu untuk terus diberikan oleh Tim Pelaksana Kegiatan agar para guru yang membutuhkan bantuan untuk membuat artikel dapat terbantu dengan baik.

\section{Simpulan dan saran}

Berdasarkan hasil kegiatan dan pembahasan yang diperoleh, maka kesimpulan yang dapat diberikan dalam kegiatan ini sebagai berikut.

1. Kegiatan yang terlaksana meliputi kegiatan: (a) pemaparan mengenai materi terkait research group berbasis lesson study pembelajaran; (b) pelaksanaan tahap plan melalui diskusi antar anggota research group; (c) pendampingan untuk tahap do; (d) Pendampingan tahap see atau refleksi pembelajaran; (e) Pendampingan analisis data penelitian dan penulisan laporan PTK; dan (f) evaluasi pelaksanaan kegiatan yang bertujuan untuk mengukur keberhasilan tujuan pelaksanaan kegiatan pengabdian.

2. Kegiatan pengabdian kepada masyarakat yang dilakukan untuk para guru KKG GUSEK 2 Tenggarang Kabupaten Bondowoso dilaksanakan dengan 2 tahap yang dilakukan pada tanggal 18 Oktober dan 18 Nopember 2017. Peserta pada tahap I adalah 32 orang $(57,14 \%)$, sedangkan pada tahap II adalah 38 orang $(67,86 \%)$ dengan jumlah total guru 56 orang. Target dalam kegiatan ini secara keseluruhan tercapai dengan baik, yaitu hampir $75 \%$ peserta yang mengikuti kegiatan pelatihan sudah memiliki laporan yang mana masih membutuhkan bimbingan lanjutan untuk semakin menyempurnakan laporan yang sudah dibuat. Kendala yang dihadapi dalam kegiatan ini diantaranya beberapa orang guru datang terlambat saat kegiatan, kondisi cukup mengganggu, namun demikian guru yang terlambat hadir dapat menyesuaikan diri dengan baik. Antusiasme para peserta pelatihan dapat dilihat dari keseksamaannya dalam memperhatikan dan mengikuti pelatihan.

Berdasarkan hasil kegiatan dan pembahasan yang diperoleh, maka saran yang dapat diberikan dalam kegiatan ini sebagai berikut. 1) Pelaksanaan kegiatan terkait dengan pengembangan kemampuan guru untuk dapat membuat sebuah laporan peneliltian tidak cukup hanya dengan pemaparan materi. Hal terpenting justru adalah pendampingan yang dapat dilakukan tanpa terikat pada waktu. Hal ini dikarenakan setiap guru juga memiliki tugas dan tanggung jawab yang tidak mungkin ditinggalkan terkait dengan pelaksanaan pembelajaran di SD tempatnya mengajar. 2) Koordinasi dengan ketua KKG perlu dilakukan dengan intensif, karena pelatihan dengan melibatkan KKG terkait dengan banyak pihak/guru dari berbagai SD. Oleh karena itu tanpa adanya kerjasama yang solid dari berbagai pihak, kesuksesan kegiatan semacam ini akan sulit diraih.

\section{Daftar Rujukan}

Barnawi \& Arifin, M. 2010. Etika dan Profesi Kependidikan. Jogjakarta: Ar-Ruzz Media.

Cajkler, W., Wood, P., Norton, J., Pedder., D. 2014. Lesson Study as a Vehicle for Collaborative Teacher Learning in a Secondary School. Professional Development in Education, 40(4): 511-529.

Halvorsen, Anne-Lise., \& Lundi, Alisa Kesler. 2013. Lesson Study and History Education. The Social Studies, 104(3): 123-129.

Masyhud, M. S. 2015. Publikasi Ilmiah dalam Rangka PKB Guru (Edisi 3 Cetakan 1). Jember: Lembaga Pengembangan Manajemen dan Profesi Kependidikan (LPMPK). 
Murtisal, Eva, Cut Nurmaliah dan Safrida. 2016. Implementasi Pembelajaran Berbasis Lesson Study Terhadap Kompetensi Pedagogik Dan Keterampilan Proses Sains Guru Biologi Sma Negeri 11 Dan Ma Negeri 3 Kota Banda Aceh. Jurnal Biotik, Vol. 4, No. 1, Hal. 81-94

Pembinaan Dan Pengembangan Profesi Guru, Buku 2. 2010. Pedoman Pelaksanaan Penilaian Kinerja Guru (PK Guru). Jakarta: Direktorat Jenderal Peningkatan Mutu Pendidik dan Tenaga Kependidikan.

Peraturan Pemerintah Republik Indonesia Nomor 74 tahun 2008 tentang guru.

Peraturan Pemerintah Republik Indonesia Nomor 19 Tahun 2005 tentang Standar Pendidik dan Tenaga Kependidikan.

Peraturan Menteri Pendidikan Nasional Republik Indonesia Nomor 16 Tahun 2007 tentang Standar Kompetensi Akademik dan Kompetensi Guru.

Rasyimah \& Prayekti . 2012. Lesson Study For Improving The Achievement Of Science For Student In Elementary School. Jurnal Pendidikan dan Kebudayaan, Vol. 18, Nomor 1

Republik Indonesia. 2005. Undang-Undang Republik Indonesia Nomor 14 Tahun 2005 Tentang Guru dan Dosen. Lembaran Negara Republik Indonesia Tahun 2005, No. 157. Menteri Hukum dan Hak Asasi Manusia RI. Jakarta.

Republik Indonesia. 2007. Peraturan Menteri Pendidikan Nasional Nomor 16 Tahun 2007 tentang Standar Kualifikasi Akademik dan Kompetensi Guru. Menteri Pendidikan Nasional RI. Jakarta.

Republik Indonesia. 2010. Peraturan Menteri Pendidikan Nasional Nomor 35 Tahun 2010 tentang Petunjuk Teknis Pelaksanaan Jabatan Fungsional Guru dan Angka Kreditnya. Menteri Pendidikan Nasional RI. Jakarta.

Republik Indonesia. 2011. Peraturan Pemerintah Republik Indonesia Nomor 46 Tahun 2011 tentang Penilaian Prestasi Kerja Pegawai Negeri Sipil. Lembaran Negara Republik Indonesia Tahun 2011, No. 121. Menteri Hukum dan Hak Asasi Manusia RI. Jakarta.

Trisnayanti, N, Wayan Sedia, dan Ketut Suma. 2014. Pengaruh Diklat Berbasis Lesson Study Terhadap Peningkatan Kompetensi Pedagogik Guru Sains dan Prestasi Belajar Siswa SMP Negeri 1 Singaraja. Jurnal Penelitian Pascasarjana Undiksha, Vol 4, No 12014

Wardhani, I G A K. \& Wihardit, K. 2011. Penelitian Tindakan Kelas. Jakarta: Universitas Terbuka.

Waris, Susilo, H., Muhdar, M., Rohman, F. 2014. The Development of Genetics Guided Inquiry Learning Tools for Blended Learning Through Lesson Study. Makalah disajikan dalam World Association of Lesson Studies International Conference 2014 in Bandung, Indonesia, 25-28 November 2014.

Waseso, M.G. 2001. Isi dan Format Jurnal Ilmiah. Makalah disajikan dalam Seminar Lokakarya Penulisan artikel dan Pengelolaan jurnal Ilmiah, Universitas Lambungmangkurat, 9-11Agustus 